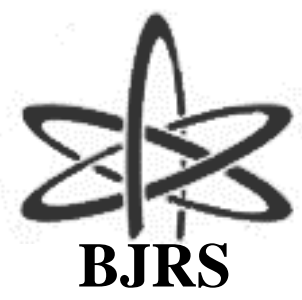

\author{
BRAZILIAN JOURNAL \\ $\mathrm{OF}$ \\ RADIATION SCIENCES \\ 08-03A (2020) 01-25
}

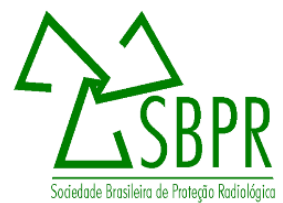

\title{
Lessons Learned: a nuclear knowledge management tool for learning about radiation accidents
}

\author{
Luis Carlos Jansen Silva, Fernando Barcellos Razuck \\ INSTITUTE OF RADIATION PROTECTION AND DOSIMETRY \\ rack@hotmail.com
}

\begin{abstract}
According to the International Atomic Energy Agency (IAEA), the lessons learned (LL) in a radiation accident are extremely important for the building of learning about accidents, identifying best practices and preventing new accidents from occurring. Thereby, it was noted that the LL identified from the accident analysis led to the adoption of a series of measures to make facilities safer and more prepared for such accidents. In this sense, the objective of this paper is to make a bibliometric review on the accidents involving radiation material, based in the main publications of the IAEA about LL. It is understood that, in relation to the dissemination of knowledge, the analysis of the LL as a tool for Nuclear Knowledge Management (NKM) is of extra relevance, not only for studies and learning in the area, but mainly for the prevention of accidents. So is evident that the analysis of the LL about radiation accidents is a powerful learning tool in the field of radiation protection, promoting the discussion about a wider knowledge over nuclear energy. It is then observed the importance of evaluating LL to strengthen the NKM.
\end{abstract}

Keywords: Lessons Learned, Nuclear Knowledge Management, Bibliometric Review, International Atomic Energy Agency, Radiation Protection, Radiation Accident. 


\title{
1. INTRODUCTION
}

\subsection{Presentation}

According to the International Atomic Energy Agency (IAEA), the lessons learned (LL) in a radiation accident are extremely important for the building of learning about accidents, identifying best practices and preventing new accidents from occurring. In this sense, the IAEA included in the Safety Standards, stated in the Fundamental Safety Principles publication, the principles for the effective management of safety [1].

In particular, in the Fundamental Safety Principles, under Principle 3, which deals with leadership and management for safety, the publication states that "processes must be put in place for the feedback and analysis of ... accidents ... so that lessons may be learned, shared and acted upon"[1]. This point is also covered in GS-R-2, where it is stated that

\begin{abstract}
...arrangements shall be made to maintain, review and update emergency plans, procedures and other arrangements and to incorporate lessons learned from research, operating experience (such as the response to emergencies) and emergency drills and exercises as part of the quality assurance programme. [1, p.7].
\end{abstract}

Thereby, IAEA, during the General Conference, in September 2011, in resolution GC(55)/RES/9, emphasized forall Member States that

\footnotetext{
...the importance...to implement emergency preparedness and responsemechanisms and develop mitigation measures at a national level, consistent with the Agency's Safety Standards and further requested "the Secretariat to continue improving methods of exchange of knowledge and experience in the area of emergency preparedness and response and strongly encouraged Member States to participate actively in this exchange" [1, p.7].
}

So, LL have been learned from investigations into a relatively large number of accidents that have occurred in different practices. The retrospective study of accidents is essential to prevention, whichis why the IAEA have devoted aconsiderable amount of resources to this area [2].

The body of knowledge gained from these investigations can, ingeneral, be envolved in accidents with: nuclear (power plants) and radioactive materials (as industrial radiography and radiotherapy) [2, 3]. In addition to published reports, another tool for dissemination of LL from accidents (LLA) is IAEA's international reporting system of unusual radiation events (RADEV) [2]. 


\subsection{The importance of Lessons Learned to Nuclear Knowledge Management}

It was verified the essential role that the study of LLA has in preventing accidents in different areas. And a practice also used by the IAEA in relation to radioactive activities is NuclearKnowledge Management (NKM). So, to IAEA, the importance of NKM is infact that building, collecting, transferring, sharing, preserving, maintaining and utilizing knowledge is essential to developing and keeping the necessary technical expertise and competences required for nuclear power programmes and other nuclear technology [4].

This is because, for the IAEA, knowledge is the most valuable asset for any radioactive installation, given that advanced and specialized knowledge in nuclear engineering and science is required for the safe and effective design, construction, licensing, commissioning, operation, maintenance and decommissioning of nuclear technology-based systems, which may have long life cycles in changing contexts [4].

According to IAEA, appropriate expertise must be developed and kept available throughout the nuclear technology life cycle, where effective Knowledge Management (KM) helps achieve this objective, so that the safe use of licensed nuclear facilities and technologies is reliant on the ongoing availability and maintenance of suitable knowledge and expertise, including an adequate understanding of related safety issues [4]. In this sense:

\footnotetext{
Recognizing the importance of nuclear knowledge management, the IAEA develops methodologies and guidance documents for planning, designing and implementing nuclear knowledge management programmes and facilitates nuclear education, providing support, networking opportunities and experience exchange. The IAEA assists Member States by providing products and services for maintaining and preserving nuclear knowledge and by promoting the use of state-of-the-art knowledge management technologies [4, n.p.].
}

In addition, it can be said that there is a direct relationship between LL and KM or NKM. For instance, radiation protection is a set of measures designed to protect humans, their offspring and the environment against possible undue effects caused by ionizing radiation from sources and technologically modified natural sources [5].

Then, when approaching learning in the face of tragedy, through the radiological accident in Goiânia, or example, one cannot fail to emphasize the importance of KM as a tool both for the training of human resources, but also in the legacies left from events of this nature $[4,6]$. So, 
The management of information and knowledge is a theme that has been widely discussed, in several spaces, in Brazil, especially in higher education organizations and institutions. This is a complex discussion that involves many aspects both because it is located at points of intersection between several fields of knowledge, notably Administration, Computer Science and Production Engineering, as well as the objective constraints of its organizational theories and practices [6, p. 55].

Thus, KM as a discipline started with information science and has since expanded to all other areas [7]. It can be inferred that:

The understanding of Knowledge Management according to the process by which strategic information is identified, analysed and interpreted with the purpose of generating new information and knowledge that support the processes of decision-making and action demonstrates that this process canbe applied in other environments other than business. Information flows are established by all human activities and Knowledge Management can be applied, according to the purpose of each enterprise, whether scientific, business or political [8, p. 15].

In this sense, LL would be the key experiences that hold some relevance for future projects, and some author's present different definitions and conceptions of LL $[9,10]$. Thus, the LL would be, in general:

a. means to make knowledge explicit, to develop it and to increase its comparability, in order to contribute to learning [11];

b. learning's obtained in the process of realizing a project, can be identified and registered at any time, to generate a knowledge base [12];

c. a foundation for innovation, by identifying the root cause of successes and failures, helping to improve the process [4].

On the other hand, the relationship between LL and KM would have the main objective of transmitting empirical knowledge to an organization (be it operational, tacit or strategic), positively impacting the results of organization, making the LL stored in a knowledge base [7].

Thus, under the view of KM, any and all experience is knowledge, and should be explicit, shared and disseminated to add value to people and organizations, so that Kmwould be the management of activities and processes, promoting knowledge through the best use and creation of individual and collective sources of knowledge $[8,10,13,14]$.

Therefore, the understanding of NKM as a process by which strategic information is identified, analyzed and interpreted in order to generate new information and knowledge that supports decision-making and action processes, demonstrates that this process can be applied in different 
environments. In this sense, the objective of this paper is to make a general review of some LLA, so that, from the NKM, analyze the main legacies with respect to the issue of radiation protection and radiological emergency that can be carried out. In this sense, this paper provides an overview of the LL and specifically considers the human actions and omissions that have resulted in an accident, focusing on accidents that have occurred at nuclear (power plants) and radiological (as industrial radiography and and radiotherapy) levels.

\section{MATERIALS AND METHODS}

Then, the mainly objective of this paper is to make a bibliometric review on the accidents involving radiactive materials, based on the publications of the IAEA about LL and LLA.

\section{RESULTS AND DISCUSSION}

It will be now present the results regarding the research on bibliometric review on IAEA about LL, that is, the main LL publications related to accidents envolving radiactive material and industrial radiography, irradiators and radiotherapy.

Thus, the results will be presented in 3 major groups of IAEA publications: 1.IAEA scientific and technical publications about LL; 2. Accidents in industrial radiography, irradiators and radiotherapy; and 3. A brief history of the major accidents involving radioactive material.

\section{IAEA SCIENTIFIC AND TECHNICAL PUBLICATIONS ABOUT LL AND LLA}

A total of IAEA scientific and technical publications can be searched by multiple parameters, as Topic and Type. Now, the publications about LL and LLA will be identified according to the Topic and Type of publications [15] :

\section{A) Topics}

The publications are classified into 14 Topics. The Topics (and their respective subdivisions) will be presented here. The total number of publications, the total number of publications on LL and 
LLA are indicated in parentheses (T/LL/LLA). Only the publications on LL and LLA (in under-

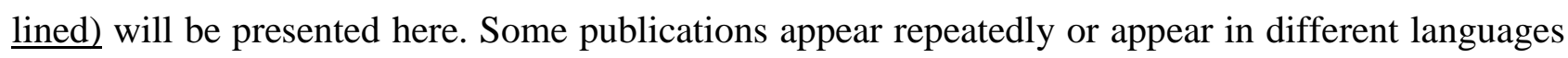
on different Topics:

1) Accident reports (16/0/0);

2) Department of Nuclear Energy (3/0/0);

2.1) Division of Nuclear Power (2/0/0);

2.1.1) International Project on Innovative Nuclear Reactors and Fuel Cycles Section (1/1/0) - "Lessons Learned from Nuclear Energy System Assessments (NESA) Using the INPRO Methodology. A Report of the International Project on Innovative Nuclear Reactors and Fuel Cycles (INPRO)" - 2009;

2.2) Division of Nuclear Fuel Cycle and Waste Technology (1/0/0);

2.2.1) Decommissioning and Environmental Remediation Section (1/0/0);

3) Nuclear power plant safety (3/1/0) - “Ageing Management for Nuclear Power Plants: International Generic Ageing Lessons Learned (IGALL)" - 2015;

3.1) Operation and maintenance of nuclear power plants $(8 / 0 / 0)$;

3.2) Construction and commissioning of nuclear power plants $(2 / 0 / 0)$;

3.3) Decommissioning of nuclear installations (2/0/0);

3.4) Design of nuclear power plants (2/1/0) - "Design Safety Considerations for Water Cooled Small Modular Reactors Incorporating Lessons Learned from the Fukushima Daiichi Accident" 2016;

4) Management systems (2/0/0);

5) Nuclear safety and security (2/0/0);

5.1) Emergency preparedness and response (EPR) (6/0/0);

5.2) Radiation protection (2/0/0);

5.2.1) Patients (1/0/0);

5.2.2) Public (1/0/0);

5.2.3) Workers (1/0/0);

5.3) Radioactive waste and spent fuel management (1/0/0);

5.3.1) Decommissioning of nuclear installations $\quad(2 / 0 / 0)$;

5.4) Security of nuclear and other radioactive material (1/0/0); 
5.4.1) Public events security (4/0/0);

5.4.2) Nuclear forensics $(2 / 0 / 0)$;

6) Nuclear technology and applications (2/1/0) -"Stress Corrosion Cracking in Light Water Reactors: Good Practices and Lessons Learned" - 2011;

6.1) Energy (8/2/0) - "Lessons Learned from the Deferred Dismantling of Nuclear Facilities" - 2018; "Lessons Learned from Nuclear Energy System Assessments (NESA) Using the INPRO Methodology. A Report of the International Project on Innovative Nuclear Reactors and Fuel Cycles (INPRO)" - 2009;

6.1.1) Nuclear power reactors (10/1/0) -“Ageing Management for Nuclear Power Plants: International Generic Ageing Lessons Learned (IGALL)"- 2015;

6.1.1.1) Fast reactors (1/0/0);

6.1.1.2) Small modular reactors $(1 / 0 / 0)$;

6.1.2) Nuclear fuel cycle (4/1/0) -"Experiences and Lessons Learned Worldwide in the Cleanup and Decommissioning of Nuclear Facilities in the Aftermath of Accidents" - 2014;

6.1.2.1) Nuclear fuel utilization (1/0/0);

6.1.3) Energy planning (2/0/0);

6.1.4) Nuclear power plant life cycle (2/0/0);

6.1.4.1) Operation and maintenance of nuclear power plants $(8 / 0 / 0)$;

6.1.4.2) Construction and commissioning of nuclear power plants (2/0/0);

6.1.4.3) Decommissioning of nuclear installations (2/0/0);

6.1.4.4) Design of nuclear power plants (2/1/0) - "Design Safety Considerations for Water Cooled Small Modular Reactors Incorporating Lessons Learned from the Fukushima Daiichi Accident" - 2016;

6.1.4.5) Sitting of nuclear facilities $(1 / 0 / 0)$;

6.1.5) Nuclear infrastructure (1/0/0);

6.1.5.1) Infrastructure development (2/0/0);

6.1.6) Research reactors (1/0/0);

6.2) Addressing environmental issues (1/1/0) - "Lessons Learned from Environmental Remediation Programmes" - 2014;

6.3) Food and agriculture (1/0/0); 
7) Assessment of contamination in agriculture (1/0/0);

8) Chernobyl Nuclear Accident (1/0/0);

9) Department of Nuclear Safety and Security (1/0/0);

9.1) Division of Nuclear Security (1/0/0);

9.2) Incident and Emergency Centre (1/0/0);

10) Fukushima Nuclear Accident (1/1/0) - "Design Safety Considerations for Water Cooled Small Modular Reactors Incorporating Lessons Learned from the Fukushima Daiichi Accident" - 2016;

11) Industrial applications (1/0/0);

11.1) Environmental remediation for industry (1/0/0);

12) International Project on Innovative Nuclear Reactors and Fuel Cycles (INPRO) (1/1/0) "Lessons Learned from Nuclear Energy System Assessments (NESA) Using the INPRO Methodology. A Report of the International Project on Innovative Nuclear Reactors and Fuel Cycles (INPRO)" - 2009;

13) Neutron activation analysis $(1 / 0 / 0)$;

14) Nuclear waste treatment (1/0/0) -"Management of Disused Sealed Radioactive Sources" 2014.

B) Type

The publications are classified into 10Types. The Types (and their respective subdivisions) will be presented here. The total number of publications, the total number of publications on LL and the total number of publications on LLA are indicated in parentheses (T/LL/LLA). Only the publications on LL and on LLA (in underlined) will be presented here. Some publications appear repeatedly or appear in different languages on different Types:

1) TECDOC Series (35/9/0) - Spent Fuel Storage Operation — "Lessons Learned" - 2013; "Experience Gained from Fires in Nuclear Power Plants: Lessons Learned" - 2004; "Planning, Managing and Organizing the Decommissioning of Nuclear Facilities: Lessons Learned" - 2004; "Design Safety Considerations for Water Cooled Small Modular Reactors Incorporating Lessons Learned from the Fukushima Daiichi Accident" - 2016; "Lessons Learned from Nuclear Energy System Assessments (NESA) Using the INPRO Methodology. A Report of the International Project on Innovative Nuclear Reactors and Fuel Cycles (INPRO)" - 2009; "Managing Human Resources in the 
Nuclear Power Industry: Lessons Learned" - 2003; "Follow-up of delayed health consequences of scute accidental radiation exposure Lessons to be learned from their medical management" - 2002; "Nuclear Power Plant Organization and Staffing for Improved Performance: Lessons Learned" 1998; "International Experience in the Implementation of Lessons Learned from the Three Mile Island Incident" - 1983;

2) Non-serial Publications (32/2/2) - "Lessons Learned from Accidents in Industrial Irradiation Facilities" - 1996; "Lessons Learned from Accidents in Industrial Irradiation Facilities (Russian $\underline{\text { Edition) }}$ " - 1998;

3) Nuclear Energy Series (22/5/0) - "Lessons Learned from the Deferred Dismantling of Nuclear Facilities" - 2018; "Experiences and Lessons Learned Worldwide in the Cleanup and Decommissioning of Nuclear Facilities in the Aftermath of Accidents" - 2014; "Redevelopment and Reuse of Nuclear Facilities and Sites: Case Histories and Lessons Learned" - 2011; "Lessons Learned from Environmental Remediation Programmes" - 2014; "Stress Corrosion Cracking in Light Water Reactors: Good Practices and Lessons Learned" - 2011;

4) Proceedings Series (10/1/0) -“Lessons Learned from the Decommissioning of Nuclear Facilities and the Safe Termination of Nuclear Activities" - 2007;

5) Technical Reports Series (10/0/0);

6) Emergency Preparedness and Response (6/5/5) - “Lessons Learned from the Response to Radia-

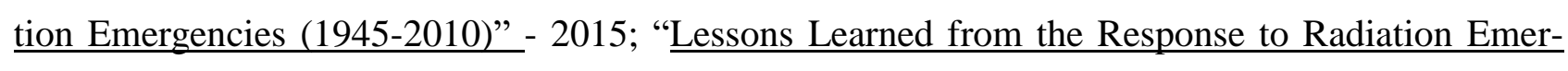
gencies (1945-2010)" - 2014; "Lessons Learned from the Response to Radiation Emergencies (1945-2010)" - 2013; "Lessons Learned from the Response to Radiation Emergencies (19452010)"- 2013; "Lessons Learned from the Response to Radiation Emergencies (1945-2010)" 2012";

7) Safety Reports Series (6/4/3) - "Lessons Learned from Accidents in Industrial Radiography" 1998; “Ageing Management for Nuclear Power Plants: International Generic Ageing Lessons Learned (IGALL)" - 2015; "Lessons Learned from Accidental Exposures in Radiotherapy" - 2000;

“Technical Approach to Probabilistic Safety Assessment for Multiple Reactor Units” - 2019;

8) Nuclear Security Series (3/0/0);

8.1) Implementing Guides (2/0/0);

9) TECDOC Series (CD-ROM) (2/0/0); 
10) INSAG Series (1/0/0).

From the total of publications, one can infer the following relationships about LL and LLA:

A) Topic - 122/12/0, which corresponds to a relationship between the total publications and LL publications of $9.8 \%$ and the total publications and LLA of $0 \%$, while the relationship between LL publications and LLA publications is $0 \%$;

B) Type - 129/26/10, which corresponds to a relationship between the total publications and LL publications of $20.2 \%$ and the total publications and LLA publications of $7.8 \%$, while the relationship between LL publications and LLA publications is $38.5 \%$.

Then, the 6 publications on accidents are:1) "Lessons Learned from the Response to Radiation Emergencies (1945-2010)" - 2015; 2) "Lessons Learned from Accidents in Industrial Irradiation Facilities" - 1996; 3) "Lessons Learned from Accidents in Industrial Radiography (1998); 4) Lessons Learned from Accidental Exposures in Radiotherapy" - 2000; 5) "International Experience in the Implementation of Lessons Learned from the Three Mile Island Incident" - 1983; 6) "Lessons Learned from the Three Mile Island Incident” - 1983 [15].

Three of these publications on accidents are briefly described, with a more general approach and the corresponding LL [15]:

I. "Lessons learned from accidents in industrial radiography" - 1998

This "Safety Report" discusses the issue of the use of ionizing radiation for technical development in medicine, industry and research. A long-established application of ionizing radiation is the use of X-rays and gamma for industrial radiography. In almost all IAEA Member States, industrial radiography is performed in companies rangingfrom multinational companies to small businesses, consisting of one or two people.

In addition, radiography is performed at thousands of sites, including shielded enclosures (fixed installations) and remote field sites, and covers many different applications. Industrial radiography accounts for about half of all accidents reported to the nuclear industry in both developed and developing countries.

This was the reason for a review of these accidents by a team of regulatory authorities, manufacturers and safety consultants. Based on a study of the circumstances of each accident and apparent deficiencies in safety, regulatory system, design and staff performance, a number of measures were identified that, if implemented, would improve safety performance. 
This report contains the results of extensive research in terms of lessons that can be learned from accidents. The information contained in this report is intended to beused by regulatory authorities, operational organizations, workers, manufacturers and customer organizations responsible for radiation protection and safety in industrial radiography.

II. "Lessons learned from accidental exposuries in radiotherapy" - 2000

In this "Safety Series" it is argued that the medical use of radiation is unique in that patients are intentionally exposed to radiation. The goal of radiation therapy is two fold: delivering a dose and dose distribution suitable for tumor control, but also minimizing complications in normal tissues. In therapeutic applications, doses are high and a deviation from the prescribed dose can have serious or even fatal consequences.

Therefore, there is a strongneed to ensureadequate radiation protection and radiation safety by verifying that all personnel involved are properly trained for their functions, that the equipment used meets the international specifications relevant to radiation safety and that the safety culture is embedded in routine activities in radiotherapy departments. Many people should interact and work together on highly technical measures and calculations, and therefore the potential for errors is great. A review of the errors shows that most are due to a human error.

The International Basic Safety Standards for Protection against Ionizing Radiation and Safety from Radiation Sources (IAEA Safety Series No. 115) require that an immediate investigation be performed whenever accidental medical exposure of patients occurs. The investigation report must be disclosed to the appropriate parties so that the lessons can be learned to avoid similar accidents or mitigate their consequences in the future.

This safety report is a collection of a large number of events that can serve as a checklist to test a facility's vulnerability to possible accidents and provide a basis for improving safety in the use of radiation in medical applications. Another objective of this report is to encourage readers to develop a questioning and learning attitude, to adopt measures for the prevention of accidents and to prepare the mitigation of the consequences of accidents if they occur.

III. "Lessons Learned from the Response to Radiation Emergencies (1945-2010)" - 2013

In this report, it is said that the IAEA Statute authorizes the IAEA to establish safety standards to protect health and minimize the danger to life and property. According to the IAEA Safety Standards Series No. SF-1, Fundamental Safety Principles, the fundamental safety objectives, safety 
principles and concepts that lay the foundation for the sesafety standards and the safety aspects of the IAEA are established. Related requirements are set forth in the safety requirements publications, while guidance on compliance with the serequirements is provided in the related Safety Guides.

The publication "Fundamentals Safety Principles" contains ten principles of safety and briefly describesits intention and purpose. Principle 9, for example, states that "arrangements should be made for emergency preparedness and response for nuclear or radiation incidents". Requirements for emergency preparedness and response to nuclear or radiological emergencies in any country are provided in the IAEA Standard Safety Series, GS-R-2, "Preparation and Response for a Nuclear or Radiological Emergency", prepared jointly by seven organizations of different countries.

Included in the safety principles set out in the publication "Fundamentals Safety Principles", they represent principles for effective safety management. In particular, in Principle 3, which deals with leadership and safety management, the publication states that "processes should be put in place for feedback and accident analys is so lessons can be learned, shared and acted upon." This point is also covered in GS-R-2, which states: "Arrangements should be made to maintain, review and update emergency plans, procedures and other arrangements and incorporate lessons learned from research, operational experience (such as emergency response The IAEA General Conference of September 2011, in resolution GC (55) / RES / 9, emphasized for all Member States the importance for implement emergency preparedness and response mechanisms and develop mitigation measures at the national level, in accordance with the Safety Standards and further requested.

The Secretariat should continue to improve methods of exchange of knowledge and experience in the area of emergency preparedness and response and encouraged Member States to participate actively in this exchange. While the primary responsibility for safety must be with the person or organization responsible for facilities and activities that give rise to radiation hazards (Principle 1 of the Publication of Fundamental Principles of Safety), the IAEA also has a responsibility to assistits Member States in improvement. Firstly, under its Statute, it is authorized to provide for the application of its standards. Secondly, one of the tasks assigned to the IAEA in accordance with Article 5a. (ii) of the Convention on Assistance in Case of a Nuclear or Radiological Accident, the emergency is to collect and disseminate information from States Parties and Member States on available methodologies, techniques and research results related to the response to nuclear accidents or emergencies radiological. 
This publication has been prepared to assist IAEA Member States in assimilating these lessons from past emergencies that reinforce the safety requirements given in the publication of GS-R-2 safety requirements. However, this report was written before the March 2011 earthquake in Japan and does not include consideration of the accident at the Fukushima Daiichi nuclear power plant at TEPCO.

\section{ACCIDENTS IN INDUSTRIAL RADIOGRAPHY, IRRADIATORS AND RADIOTHERAPY}

The following analysis was based on investigations of individual accidents in the IAEA Accident Report Series [2]. Three summary tables will be presented: Table 1 on accidents involving radiotherapy patients, Table 2 on industrial accidents and Tables 3 and 4 on loss of sources that caused deaths or several injuries, respectively. Also, after each table, the main LL will be presented.

Table 1: Accidents involving radiotherapy patients

\begin{tabular}{c|c|c|l}
\hline Country & Year & $\begin{array}{c}\text { No of patients } \\
\text { affected }\end{array}$ & \multicolumn{1}{|c}{ Causes and main contributing factors } \\
\hline USA & $\begin{array}{c}1974- \\
76\end{array}$ & 426 & $\begin{array}{l}\text { Co-60 dose calculations based on erroneous decay chart } \\
\text { (varying overdoses); no independent verification of decay } \\
\text { charts and dose calculations; More than two years without } \\
\text { beam measurements; Physics manpower and attention shifted } \\
\text { to others tasks, such as a new accelerator }\end{array}$ \\
\hline Germany & $1986-197$ & 86 & $\begin{array}{l}\text { Co-60 dose calculations based on erroneous dose tables; } \\
\text { varying overdoses; no independent determination of the dose } \\
\text { rate }\end{array}$ \\
\hline UK & 1988 & 207 & $\begin{array}{l}\text { Error in the calibration of a Co-60 therapy unit (25\% over- } \\
\text { dose); no independent calibration of the beam }\end{array}$ \\
\hline Spain & 1990 & 27 (18 deaths & $\begin{array}{l}\text { Error in the identification of Cs-137 brachytherapy sources (- } \\
\text { 20 to +10\% dosimetry errors); no independent determination } \\
\text { of source strength }\end{array}$ \\
\hline $\begin{array}{l}\text { Error in the maintenance of a clinical linear accelerator; Pro- } \\
\text { cedures for transferring machine from and to maintenance } \\
\text { (informing physicists) not followed; Conflicting signals and } \\
\text { displays ignored; Procedures for periodic beam verifications } \\
\text { (QA) not implemented; Overdosage ranging from 200\% to } \\
\text { 700\% }\end{array}$ \\
\hline UK & $1982-$ & nearly 1,000 & $\begin{array}{l}\text { Inappropriate commissioning of a computerized Treatment; } \\
\text { Planning System (5-30\% underdosage); No written proce- }\end{array}$ \\
\hline
\end{tabular}




\begin{tabular}{c|c|c|l}
\hline USA & 1992 & $\begin{array}{c}1 \text { (death from } \\
\text { radiation) }\end{array}$ & $\begin{array}{l}\text { dures for commissioning and use } \\
\text { Brachytherapy source (High Dose Rate) left inside the pa- } \\
\text { tient; Source dislodged from equipment; Conflicting monitor } \\
\text { signals and displays ignored }\end{array}$ \\
\hline $\begin{array}{c}\text { Costa } \\
\text { Rica }\end{array}$ & 1996 & $\begin{array}{c}115 \text { (at least 17 } \\
\text { deaths from ra- } \\
\text { diation) }\end{array}$ & $\begin{array}{l}\text { Error in calculation during the calibration of Co-60 therapy } \\
\text { Unit; lack of independent calibration and of QA; Recommen- } \\
\text { dations from an external audit ignored }\end{array}$ \\
\hline
\end{tabular}
Source: [b].

As LL, a structured and systematic approach is needed of activities; licensing of a radiotherapy department should be conditional on a comprehensive quality assurance programme; embrace treatment prescription, planning and delivery, as well as the organization of the radiotherapy department; maintenance of radiotherapy equipment and the staff qualifications and training; maintain the level of safety over time, which means looking at indicators of slow degradation. For this purpose, inspectors should not only look for formal compliance, but also for early warnings of potential problems $[\mathrm{b}]$.

Table 2: Accidents involving industrial irradiation facilities

\begin{tabular}{|c|c|c|c|c|c|}
\hline Year & Place & Type Facility & OfOutcome & $\begin{array}{l}\text { Estimated } \\
\text { Dose }\end{array}$ & Remarks \\
\hline 1965 & Illinois,USA & Accelerator & $\begin{array}{l}\text { One person } \\
\text { amputation of leg and } \\
\text { arm }\end{array}$ & $\begin{array}{c}290- \\
2400 \mathrm{~Gy}\end{array}$ & \\
\hline 1967 & Pittsgurg, USA & Accelerator & $\begin{array}{l}3 \text { irradiated people, one } \\
\text { of wichrequired the } \\
\text { amputtation of both } \\
\text { hands }\end{array}$ & $1-6 \mathrm{~Gy}$ & $\begin{array}{ll}\text { Failure } & \text { of } \\
\text { interlocks } & \end{array}$ \\
\hline 1974 & $\begin{array}{l}\text { New Jersey, } \\
\text { USA }\end{array}$ & Gamma & $\begin{array}{l}1 \text { person, Acute } \\
\text { radiation }\end{array}$ & $\sim 4 \mathrm{~Gy}$ & \\
\hline 1975 & Stimos, Italy & Gamma & 1 fatality & $\sim 12 \mathrm{~Gy}$ & \\
\hline 1977 & $\begin{array}{l}\text { New Jersey, } \\
\text { USA }\end{array}$ & Gamma & $\begin{array}{l}\text { person, Acute } \\
\text { syndrome }\end{array}$ & $\sim 2 \mathrm{~Gy}$ & $\begin{array}{l}\text { Short } \\
\text { exposure, } \\
\text { because he } \\
\text { realized that } \\
\text { the source } \\
\text { was exposed } \\
\text { and left } \\
\text { immediately }\end{array}$ \\
\hline 1982 & Kjeller, & Gamma & 1 fatality & $\sim 22 \mathrm{~Gy}$ & \\
\hline
\end{tabular}




\begin{tabular}{|c|c|c|c|c|c|}
\hline & Norwat & & & & \\
\hline 1989 & $\begin{array}{l}\text { San Salvador, } \\
\text { El Salvador }\end{array}$ & Gamma & 1 fatality & $\sim 8 \mathrm{~Gy}$ & $\begin{array}{l}\text { Two other } \\
\text { persons with } \\
\text { whole body } \\
\text { doses of } 2.9- \\
3.7 \text { Gy }\end{array}$ \\
\hline 1990 & Soreq, Israel & Gamma & 1 fatality & $\sim 10-20$ Gy & \\
\hline 1991 & $\begin{array}{c}\text { Nesvizh, } \\
\text { Belarus }\end{array}$ & Gamma & 1 fatality & $\sim 11 \mathrm{~Gy}$ & \\
\hline 1991 & $\begin{array}{l}\text { Hanoi, Viet } \\
\text { Nam }\end{array}$ & Accelerator & $\begin{array}{l}\text { Amputation of one } \\
\text { hand and fingers of the } \\
\text { other }\end{array}$ & $\sim 10-50 \mathrm{~Gy}$ & \\
\hline 1991 & $\begin{array}{l}\text { Maryland, } \\
\text { USA }\end{array}$ & Accelerator & $\begin{array}{l}\text { Amputation of four } \\
\text { fingers of each hand }\end{array}$ & $\sim 55 \mathrm{~Gy}$ & \\
\hline 1991 & $\begin{array}{l}\text { Forbach, } \\
\text { France }\end{array}$ & Accelerator & Skin lesions & $\sim 40 \mathrm{~Gy}$ & \\
\hline
\end{tabular}

Source: [b].

As LL, long as technological safety barriers remain effective, the probability of an accident with an irradiator is extremely low; the operational safety programme should ensure that all safety interlocks remain effective over time, sothat the overall probability is not increased by the removal of any of the layers; for irradiators, maintenance of these systems and trust in themis essential to the behaviour of staff; the recommendations given earlier for industrial radiography, with respect to illustrating the consequences with pictures for training purposes, praising safework rather that production, and close supervision with the objective of detectinge arly signs of degradation of safety, are also valid for irradiators; the recommendations given for industrial radiography with respect to licensing and inspection procedures are also applicable to irradiators; at the application stage the following issues should be addressed: What are the rules in case of conflicting signals? Who is responsible for arranging maintenance and repairs? What is the policy with regard to spare monitors or other devices? What is the operator expected to do when there is a false alarm? Which supervisory measures and policy statements are in place to ensure sufficient contact between the operator and radiation protection officer (RPO) to detect the early failure of safety systems, unauthorised tampering of safety systems, or failure to report and/or record a safety event? [b]. 
Table 3: Accidents involving loss of source that caused deaths

\begin{tabular}{|c|c|c|c|c|c|c|}
\hline Year & Place & $\begin{array}{l}\text { Radionu } \\
\text { clide }\end{array}$ & Source from & $\begin{array}{l}\text { Estimated } \\
\text { Dose }\end{array}$ & $\begin{array}{c}\text { Number } \\
\text { of } \\
\text { deaths }\end{array}$ & Remarks \\
\hline 1962 & $\begin{array}{c}\text { Mexico City } \\
\text { Mexico }\end{array}$ & Co-60 & $\begin{array}{l}\text { Industrial } \\
\text { radiography }\end{array}$ & $9.9-52 \mathrm{~Gy}$ & 4 & \\
\hline 1963 & China & Co-60 & $\begin{array}{l}\text { Industrial } \\
\text { irradiator }\end{array}$ & $0.2-80 \mathrm{~Gy}$ & 2 & $\begin{array}{l}\text { Source taken home } \\
\text { from a burial place } \\
\text { (waste repository) }\end{array}$ \\
\hline 1984 & Morocco & Ir-192 & $\begin{array}{l}\text { Industrial } \\
\text { radiography }\end{array}$ & Unknown & 8 & $\begin{array}{l}\text { loss of control of } \\
\text { source; (failure to } \\
\text { control retraction to } \\
\text { shielding) }\end{array}$ \\
\hline 1987 & $\begin{array}{c}\text { Goiania, } \\
\text { Brazil }\end{array}$ & Cs-137 & $\begin{array}{l}\text { Medical } \\
\text { teletherapy }\end{array}$ & $\begin{array}{c}\text { Up to } 7 \\
\text { Gy ext and } \\
\text { int }\end{array}$ & 4 & $\begin{array}{l}\text { Radiation unit with } \\
\text { source unsecured } \\
\text { after } \\
\text { decommissioning }\end{array}$ \\
\hline 1992 & China & Co-60 & $\begin{array}{l}\text { Industrial } \\
\text { irradiator }\end{array}$ & $\begin{array}{c}.25-10 \mathrm{~Gy} \\
\text { local }\end{array}$ & 3 & $\begin{array}{l}\text { Source taken home } \\
\text { from an irradiator } \\
\text { during } \\
\text { decommissioning }\end{array}$ \\
\hline 1994 & $\begin{array}{l}\text { Tammiku, } \\
\text { Estonia }\end{array}$ & Cs-137 & $\begin{array}{c}\text { Waste } \\
\text { repository }\end{array}$ & $\begin{array}{c}4 \text { Gy } \\
\text { whole } \\
\text { body, } \\
1800 \text { local }\end{array}$ & 1 & $\begin{array}{l}\text { loss of control of } \\
\text { source; unsecured } \\
\text { waste storage }\end{array}$ \\
\hline 1997 & Georgia & Co-60 & $\begin{array}{l}\text { Medical } \\
\text { teletherapy }\end{array}$ & Unknown & 1 & $\begin{array}{l}\text { Source about to be } \\
\text { returned; unsecured } \\
\text { near a station }\end{array}$ \\
\hline
\end{tabular}

Source: [b].

As LL, a mobile radiography sources are the most important contributor to this type of accident; the typical scenario was a radiography source that dropped from the radiography device and was placed in a person'spocket; in many of these accidents, the source was dropped at the radiography site, and was picked up by a construction worker who was not associated with the use of the source and therefore not aware of the potential hazard; accidents have also occurred when sources have fallen out of unlocked exposure devices during transportation and resulted in the exposure of several members of the public. 
Table 4: Accidents involving loss of source that caused several injuries

\begin{tabular}{|c|c|c|c|c|c|c|}
\hline Year & Place & $\begin{array}{c}\text { Radionucli- } \\
\text { de }\end{array}$ & Activity & $\begin{array}{c}\text { Source } \\
\text { from }\end{array}$ & Dose & Consequences \\
\hline 1968 & $\begin{array}{l}\text { La Plata, } \\
\text { Argentina }\end{array}$ & Cs-137 & Unknown & $\begin{array}{c}\text { Industrial } \\
\text { radiography }\end{array}$ & $\begin{array}{l}\text { Local } \\
\text { dose } \\
\text { from }\end{array}$ & $\begin{array}{l}\text { Amputation of } \\
\text { both legs, } \\
\text { permanent sterility }\end{array}$ \\
\hline 1971 & $\begin{array}{l}\text { Chiba, } \\
\text { Japan }\end{array}$ & Ir-192 & $5.26 \mathrm{Ci}$ & $\begin{array}{c}\text { Industrial } \\
\text { radiography }\end{array}$ & $\begin{array}{l}\text { From } \\
0.15 \text { to } \\
1.3 \mathrm{~Gy}\end{array}$ & $\begin{array}{l}\text { whole body Six } \\
\text { persons } \\
\text { (construction } \\
\text { workers) exposed, } \\
\text { three of them with } \\
\text { acute syndrome }\end{array}$ \\
\hline 1978 & Algeria & Ir-192 & $25 \mathrm{Ci}$ & $\begin{array}{c}\text { Industrial } \\
\text { radiography }\end{array}$ & $\begin{array}{c}1 \text { to } 1.4 \\
\text { Gy }\end{array}$ & $\begin{array}{l}\text { whole body, } 25 \text { Gy } \\
\text { skin dose } \\
\text { Irradiation of a } \\
\text { family, including } \\
\text { two children, } \\
\text { amputation of } \\
\text { fingers, grafting } \\
\text { and flap at the } \\
\text { buttock, injury in } \\
\text { the mouth, four } \\
\text { other patients } \\
\text { suffered acute } \\
\text { syndrome }\end{array}$ \\
\hline 1979 & $\begin{array}{c}\text { Los } \\
\text { Angeles, } \\
\text { USA }\end{array}$ & Ir-192 & $28 \mathrm{Ci}$ & $\begin{array}{c}\text { Industrial } \\
\text { radiography }\end{array}$ & unknown & $\begin{array}{l}11 \text { persons } \\
\text { exposed, one of } \\
\text { them needed skin } \\
\text { drafting at the } \\
\text { buttock }\end{array}$ \\
\hline 1983 & $\begin{array}{l}\text { Ciudad } \\
\text { Juárez, } \\
\text { Mexico }\end{array}$ & Co-60 & $15 \mathrm{TBq}$ & Teletherapy & $\begin{array}{l}3.0 \text { to } 7.0 \\
\text { Gy(five } \\
\text { persons) } \\
\text { and from } \\
0.25 \text { to } \\
3.0 \mathrm{~Gy} \\
(75 \\
\text { persons }\end{array}$ & Acute syndrome \\
\hline 1996 & Iran & unknown & unknown & $\begin{array}{c}\text { Industrial } \\
\text { radiography }\end{array}$ & $\begin{array}{l}\text { Local } \\
\text { dose } \\
\text { from } \\
\end{array}$ & $\begin{array}{l}11 \text { people with } \\
\text { radiation injuries }\end{array}$ \\
\hline 1996 & $\begin{array}{c}\text { Lilo, } \\
\text { Georgia }\end{array}$ & Cs-137 & $\begin{array}{c}\text { Four } \\
\text { sources, } 150\end{array}$ & $\begin{array}{l}\text { Sources for } \\
\text { exercises by }\end{array}$ & $\begin{array}{c}\text { Local } \\
\text { dose }\end{array}$ & Injuries \\
\hline
\end{tabular}




\begin{tabular}{c|c|c|c|c|c|l}
\hline & & $\begin{array}{c}\text { GBq (4 Ci) } \\
\text { each }\end{array}$ & $\begin{array}{c}\text { the army, } \\
\text { were later } \\
\text { abandoned }\end{array}$ & from & \\
\hline 1999 & $\begin{array}{c}\text { Yanango, } \\
\text { Perú }\end{array}$ & Ir-192 & unknown & $\begin{array}{c}\text { Industrial } \\
\text { radiography }\end{array}$ & $\begin{array}{c}\text { Local } \\
\text { dose } \\
\text { from }\end{array}$ & Amputation of leg \\
\hline 1999 & $\begin{array}{c}\text { Istanbul, } \\
\text { Turkey }\end{array}$ & Co-60 & unknown & Teletherapy & $\begin{array}{c}\text { Local } \\
\text { dose } \\
\text { from }\end{array}$ & $\begin{array}{l}\text { 10 persons } \\
\text { with acute } \\
\text { syndrome }\end{array}$ \\
\hline
\end{tabular}

Source: [b].

As LL, the simple knowledge of these facts should lead to straight forward regulatory actions to prevent major accidents arising from loss of control of sources; the first priority should be the verification that sources in industrial radiography, irradiators and medical teletherapy are under control; in developing countries, the smal lnumber of irradiators and medical teletherapy facilities should make this control relatively straight forward; the control of industrial radiography sources is, however, complicated by the fact that mobile sources may be lost any time during operation or transport; the majority of mobile radiography devices house sources of Ir-192, of the order of TBq (a few tens of Ci); since irdium-192 has a relatively short half-life, sources older than two years will not pose a significant threat and therefore priority should focus on iridium sources lost in recent months and on any Cs-137 and Co-60 sources.

\section{A BRIEF HISTORY OF THE MAJOR ACCIDENTS INVOLVING RADIOACTIVE MATERIAL}

A total of 10 accidents involving radioactive materials were identified, listed in chronological order and the respective LL (with a briefly description and the corresponding LL) [15-20]:

1) Kyshtym (Ozyorsk - 1957) - The Mayak plant in the Soviet Union suffered a failure in the cooling system of the nuclear waste storage compartment, which caused an explosion in a tank containing 80 tons of radioactive material. The gas cloud contaminated the region within a radius of $800 \mathrm{~km}$. The event was called "the Kyshtym disaster". About 10,000 people were evacuated, with no explanation from the government. At least 200 deaths were recorded because of exposure to radiation; 
2) Windscale (1957) - During the Second World War, England also sought to develop nuclear weapons. The rush to make an atomic bomb in Windscale led to a fire in the reactor, leaking radioactive material into the atmosphere. It caused more than two hundred cases of cancer among neighboring communities;

3) Yucca Flat (1970) - This region of intense nuclear tests is located in Nevada, $65 \mathrm{~km}$ from Las Vegas. In December 1970, a high-powered device was detonated underground, but caused cracking, which resulted in radioactive debris in the atmosphere. About 86 workers were exposed to radiation. It is not known what happened to the employees. Currently deactivated, the region received its last test in 1992;

4) Bohunice (1977) - The accident at the Bohunice plant in Czechoslovakia (now divided into Czech Republic and Slovakia) occurred after a fuel change. The moisture absorbers that covered the fuel rods were not removed in the correct way. As a consequence, the fuel overheated, leading to corrosion of the reactor. According to the IAEA, there are no adequate estimates of injuries or deaths because, at the time, the accident would have been covered by the Soviet government. What is known is that the radioactive gases spread throughout the plant;

5) Three Miles Island (1979) - The North American nuclear plant at Three Miles Island in Pennsylvania was the scene of the worst nuclear accident up until the 80s. It was an accident caused by equipment failure and operational error in evaluating reactor conditions. The equipment failure caused a gradual loss of cooling water in the reactor core which resulted in a partial melting of the element-fuel rods, with release of radioactive material inside the building, including gases such as Xenon (Xe), Krypton (Kr) and also traces of iodine (I) released into the atmosphere;

6) Chernobyl (1986) - The Chernobyl accident is considered to be the largest nuclear disaster in history, resulting in the exposure of people in the regions known today as Belarus, Russia, Ukraine and the population of several European countries. The accident occurred because the on-call team wanted to do tests in Unit 4, requested by the then-Soviet State Atomic Energy Committee, to increase reactor safety. This procedure isolated the reactor, since, with the control rods raised, followed with little amount of water circulating in the nucleus, safety systems turned off and with the increase of the steam and the internal pressure, these conditions, made it impossible to control. Studies after the accident indicated that the reactor became highly unstable at low power, and this fault was unknown to the operators. For the test to happen, the staff on duty broke certain safety 
rules. Among other errors, the officials involved in the episode interrupted the circulation of the hydraulic system that controlled the reactor temperatures. Thus, even when operating at a lower capacity, the reactor had entered a process of overheating that can not be reversed. In a few moments the formation of an immense ball of fire created an explosion of the reactor rich in Uranium-235, chemical element of great radioactive power. With this, the Chernobyl plant released a lethal amount of radioactive material that contaminated a large atmospheric region. In comparative terms, the radioactive material released at that time was four hundred times greater than the bombs used in the bombing of Hiroshima and Nagasaki at the end of World War II;

7) Goiania (1987) - The accident in Goiania, known as the "Césio-137" accident, is considered the largest radiological accident in the world, placing Brazil in the list of countries involved in a tragic radioactive accident. The accident occurred from the violation of a highly radioactive cesium 137 source (with activity of 50.9 (TBq or $1375 \mathrm{Ci}$ ), which was spread in the environment, causing the contamination of several locations. After 15 days, Brazilian Nuclear Energy Commission (CNEN) was informed of the accident, which in turn notified the IAEA. An emergency plan was then launched, with the participation of CNEN and various institutions, such as the Radiation Protection and Dosimetry Institute (IRD). The Goiania accident is considered by the IAEA as the worst event with radioactive sources, and is responsible for the IAEA publishing periodically details of the accident and the lessons identified, being available to the public. It is classified in the International Scale of Nuclear Accidents and Radiological (INES) level 5, being the only radiological accident outside such nuclear facilities. The accident occured due to a series of errors, such as the abandonment of an irradiator used in the radiotherapy service of a local hospital that contained a Cs-137 chloride capsule, due to the lack of information of the local residents, exposing more than one thousand individuals and generating a trace of which affected 129 people. Of these, 49 were hospitalized with severe symptoms and, after intensive treatment, four did not resist and eventually died;

8) Seversk (1993) - The city of Seversk, in the Siberia region, houses nuclear reactors and chemical industries for the separation and processing of uranium and plutonium. The Soviet Union did not allow the city to appear on the map, a fact that changed in 1992, following a decree by Boris Yeltsin. Soon after, in 1993, the Tomsk-7 plant suffered an accident, in which a tank with 
radioactive substances exploded. A radioactive cloud formed in the region, which today is closed and can only be visited by invitation. The number of victims is unknown;

9) Tokaimura(1999) - $100 \mathrm{~km}$ from Tokyo, the host city of the Japanese nuclear industry was the scene of an accident that exposed more than 600 people to high radiation in 1999. Employees of a uranium reprocessing company were exposed to an extreme dose of the radioactive metal in a reactor deactivated a year previous, which suffered an uncontrolled reaction, leaking radiation.

10) Fukushima (2011) - Located about $250 \mathrm{~km}$ north of Tokyo, the Daiichi nuclear power plant in Fukushima suffered damage in three of its six reactors after a level 9-magnitude earth quake hit the country. Japanese authorities have stated that the levels of released radiation were high, almost disturbing. The disaster was classified with grade 5 in the International Scale of Nuclear Accidents (INES). After that, Japaneses cientists intend to create a nuclear mini-fusion reactor in order to better understand the 2011 accident and prepare properly in case of new disasters.

\section{CONCLUSION}

It was noted that the problems identified from the accident analys is led to the adoption of a series of measures to make the installations safer and more prepared for such accidents. Thus, it was sought to evidence radioactive accidents as a learning tool in the field of nuclear energy science, opening space for discussions of a broader knowledge on KM.

It isunderstood that the analysis of the LL as a tool for NKM is of extreme relevance, not only for the prevention of accidents, but also knowing how to act. Therefore, the importance of inserting $\mathrm{KM}$ in radiation protection and emergency, in order to create means of sharing knowledge, preserving the existing knowledge and stimulating new knowledge produced from the progress of the sciences and the advances of new technologies.

This is because, generally, a radiological accident is seen in a very negative way because it brings damage to people and the environment. However, it is necessary to observe that even after a tragedy, one canal so learn and drawlessons, which will serve as guiding tools so that events of this nature will not happen again, and in the unfortunate event that they do happen, there is a clear safe reaction for all parties involved. 
In addition, since the discovery of radiation and the harmit can cause by its misuse, international organizations have been concerned with more effective protection. It is because radiation protection is a set of measures designed to protect humans, their offspring and the environment against possible undue effects caused by ionizing radiation from man-made sources and sources technologically altered, while an accident can bec onsidered any unintentional event, including operating errors and equipment failures, whose actual or potential consequences are relevant.

From a radiological protection point of view, nuclear accidents are those occurring in facilities such as nuclear reactors and nuclear fuel cycle facilities. On the other hand, radiological accidents involve sources of ionizing radiation used in various practices and can occur anywhere.

In Brazil, the use of nuclear energy is for peaceful purposes, so it is known that the use of radiation in an erroneous way and in an unjustified way canbring about detriment rather than benefits.

However, a more democratic knowledge is necessary in this area, because it can be observed that in the science of ionizing radiation, the management of a knowledge becomes necessary, even for a complex subject and is still not very widespread in Brazil. CNEN also learned important lessons from the accident in Goiânia, teachings and techniques were boosted after the event, as well as greater controls of radioactive sources was introduced. Today in Brazil, there is an up-to-date, integrated register with strict usage and disposal rules. For example, Cesium-137 is a by product of uranium, that is, it can not be found in nature, it is normally produced in Germany or England, if a clinic or a Brazilian hospital wants to import a device with a cesium source, is possible to know exactly who is the importer, for what will be the use and address of the product.

CNEN also has a agreement for the return of radioactive sources to all nations, which means that after 10, 20, or 30 years of use, the source will be returned to the country of origin.

It should be noted that the accidents at Chernobyl and Three Miles Island also served to build the nuclear knowledge management. In the Chernobyl issue, due to the recklessness of professionals and a severe lack of a safety knowledge and training the accident occured, another relevant factor is given because the design of the reactor did not have security systems that could identify and avoid an accident due to the combination of circumstances of this nature, that is, voluntary blocking of the technical protection system combined with violations of operational procedures. 
The first cause of the accident was a rather unlikely combination of breaches of procedures and operating rules committed by the staff of the plant. With regard to Three Miles Island, lessons learned in this accident include the need to integrate emergency plans: conventional + nuclear; the need for a well-defined chain of command; the importance of communication with the media. The crash was mainly caused by a combination of human errors, design deficiencies, and mechanical and electronic component failures.

In addition to being the largest nuclear accident in United States history, it was responsible for permanently changing all regulations and oversight bodies of such facilities. The population's fear and distrust increased, and the measures of control and management of the facilities began to be analyzed with greater care. Thus, it is understood that the problems identified from the careful analysis of the events occurred in the accident end up leading to the adoption of a series of measures, in order to make the installations safer and prepared for this type of occurrence.

Regarding the term LL, although its approach is present in several IAEA publications, few of them use LL in its title (9.8\% to Topic and $20.2 \%$ to Type), while to LLA is even smaller ( $0 \%$ to Topic and $7.8 \%$ to Topic). It is understood that, although references to LL are found in publications, the term seems to be better understood only in recent years.

However, compared to the total number of publications on LL, publications on LLA rise to $38.5 \%$ (in Type), which means that the LLA is relevant in relation to the total LL analysis.

In addition, for the researcher of the area, this papers is interesting because show that the IAEA periodically conducts studies and reports on various subjects related to practices with radioactive material. Thus, is possible find bibliographic references on nuclear activities, making understand that the IAEA is concerned with the elaboration of documents that serve as a reference, with the main objective of reporting LL, LLA and good practices, which strengthens the concept KM and NKM.

\section{REFERENCES}

[1] IAEA. International Atomic Energy Agency. Lessons Learned from the Response to Radiation Emergencies (1945-2010). Emergency Preparedness and Response, 2015. 
[2] ORTIZ, P.; ORESEGUN, M.; WHEATLEY. J. Lessons from Major Radiation Accidents. IAEA, T-21-1, P-11-230, 2000.

[3] SILVA, L. C. J.; RAZUCK, F. B. Knowledge management in radiation protection: The Goiania accident - learning in the face of tragedy. Brazilian Journal of Radiation Sciences, 2018.

[4] IAEA. Nuclear knowledge management. Available at: https://www.iaea.org/topics/nuclearknowledge-management. Last acessed: 15 dez. 2019.

[5] PMI. Project Management Institute. Um Guia do Conjunto de Conhecimentos em Gerenciamentos de Projetos: Guia PMBOK. 4ed. Pennsylvania: Four Campus Boulevard, 2008.

[6] WILliamS, T. How do organizations learn from projects? In: Proceedings of PMI Research Conference $[\mathrm{CD}]$, Montreal, Canada, Project Management Institute, Newtown Square, PA, 2006.

[7] KAMSUFOGUEM, B.; COUDERT, T.; BELER, C.; GENESTE, L. Knowledge formalization in experience feedback processes: An ontology-based approach. Computers in Industry, v. 59, n. 7, p. 694-710. doi: 10.1016/j.compind.2007.12.014, 2008.

[8] CEN. Comité Européen de Normalisation. European Guide to good Practice in Knowledge Management CWA 14924, 2004. Available at:<ftp://cenftp1.cenorm.be/PUBLIC/CWAs/eEurope/KM/CWA14924-04-2004-Mar.pdf> . Last Accessed: 12 de abr. 2017.

[9] SCHINDLER M., EPPLER M. J. Harvesting project knowledge: a review of project learning methods and success factors. International Journal of Project Management, v. 21, p. 219228, 2003.

[10] FERENHOF, H. A.; FORCELLINI, F. A.; VARVAKIS, G. Lições Aprendidas: Agregando Valor ao Gerenciamento de Projetos. Revista de Gestão e Projetos - GeP, São Paulo, v. 4, n. 3, p 197-209, set./dez., 2013.

[11] BAAZ, A.; AB, E.; HOLMBERG, L.; SANDBERG, A. B.; AB, E. Lessons learned Appreciating Lessons Learned. IEEE Software, 27(4): 72-79, 2010.

[12] PMI. Project Management Institute.Um Guia do Conjunto de Conhecimentos em Gerenciamentos de Projetos: Guia PMBOK. 4ed. Pennsylvania: Four Campus Boulevard, 2008. 
[13] SANTOS, C. R.O Gestor Educacional de uma Escola em Mudanças. 1 ed.- São Paulo: Pioneira, 2002.

[14] SOUZA, D. C. B.; VICENTE, R.; ROSTElATO, M. E. C.; BORGES, J. F.; TIEZZI, R.; JUNIOR, F. S. P.; SOUZA, C.; RODRIGUES, B.; BENEGA, M.; SOUZA, A.; SILVA, T. Chernobyl - O Estado da Arte. International Joint Conference RADIO 2014, Gramado, RS, Brazil, August 26-29, Sociedade Brasileira de Proteção Radiológica - SBPR, 2014.

[15] IAEA. Publications advanced search - Lessons Learned. Available at:< https://www.iaea.org/publications/search?keywords=lessons+learned\&Search=Search>. Last Accessed: 12 de abr. 2020.

[16] O GLOBO. Maiores acidentes nucleares da história. Available at:< http://educacao.globo.com/artigo/maiores-acidentes-nucleares-da-historia.html>. Last Accessed: 12 de abr. 2017.

[17] XAVIER, A. Marcos da História da Radioatividade e Tendências Atuais. Quim. Nova, Vol. 30, No. 1, 83-91, 2007.

[18] CNEN. Comissão Nacional de Energia Nuclear. Relatório DR 134/86 - 2 / 2, 1986.

[19] Gomes, A.; GOMES, M. L.; FERNANDES, E.; NETO, R.; APRIGIO, A. Gestão do Conhecimento nas Organizações: A importância do ciclo do Conhecimento. XXXII ENCONTRO NACIONAL DE ENGENHARIA DE PRODUÇÃO - Desenvolvimento Sustentável e Responsabilidade Social: As Contribuições da Engenharia de Produção2012.

[20] IAEA. INTERNATIONAL ATOMIC ENERGY AGENCY. The radiological accident in Goiania, Vienne, 1988. 